\title{
Evaluation of Creep Characteristics of Single- Staple Furniture Joints Made of Different Wood Species
}

\section{Procjena obilježja puzanja spojeva namještaja s klamericom izrađenih od različitih vrsta drva}

\author{
Original scientific paper • Izvorni znanstveni rad \\ Received-prispjelo: 28. 4. 2020. \\ Accepted-prihvaćeno: 14. 1. 2021. \\ UDK: $630 * 812.77 ; 630 * 824.22 ; 630 * 824.521$ \\ https://doi.org/10.5552/drvind.2021.2021
}
(c) 2021 by the author(s). Licensee Faculty of Forestry and Wood Technology, University of Zagreb. This article is an open access article distributed under the terms and conditions of the Creative Commons Attribution (CC BY) license.

\begin{abstract}
In this study, creep characteristics of single stapled furniture joints made of Scotch pine, alder and beech wood under three different load levels were considered. Load levels were determined as $30 \%$, 40\% and $50 \%$ of the maximum load obtained as a result of static shear test before creep load and applied to wood joints. Laboratory test results showed that the highest creep deformation was observed in the joints made of Scotch pine with the lowest density, while the lowest creep deformation was observed in the joints made of beech with the highest density. In addition, the joints were exposed to lowest creep deformation at the $30 \%$ load level, then the creep deformation of the joints increased at $40 \%$ load level and it reached the highest value at $50 \%$ load level. As a result of creep test, deformation in single stapled joints made of Scotch pine, alder and beech were determined as $2.74 \%, 3.71 \%$ and $4.37 \%$ of the deformation that occurred as a result of static shear test performed before creep test, respectively. Ultimately, the overall average creep deformation value of a single staple wood joint under creep loading was determined as $3.61 \%$.
\end{abstract}

Keywords: creep; load level; single staple; wood joint

SAŽETAK • U radu su istraživana obilježja puzanja spojeva namještaja s klamericom izrađenih od borovine, johovine $i$ bukovine pri različitim stupnjevima opteréenja. Stupnjevi opterećenja definirani su kao 30, 40 i 50\% najvećeg opterééenja dobivenoga kao rezultat statičkoga smičnog ispitivanja prije opterećenja pri puzanju te su primijenjeni na drvne spojeve napravljene klamericom. Rezultati laboratorijskih ispitivanja pokazali su da je najveća deformacija puzanja zabilježena na spojevima izrađenima od borovine, koja ima najmanju gustoću, a najmanja je deformacija puzanja uočena na spojevima od bukovine, koja ima najveću gustoću. Usto, najmanja deformacija puzanja spojeva zabilježena je pri stupnju opterećenja od $30 \%$, zatim se deformacija puzanja povećala pri stupnju opterećenja od $40 \%$ i dosegnula najveću vrijednost pri stupnju opterećenja od $50 \%$. Rezultati ispitivanja puzanja pokazali su da je deformacija spojeva s klamericom izrađenih od borovine, johovine i bukovine iznosila 2,74, 3,71 i 4,37 \% deformacije koja je rezultat statičkoga smičnog naprezanja provedenoga prije ispitivanja puzanja. $U$ konačnici, ukupna prosječna vrijednost deformacije puzanja drvenog spoja s klamericom iznosila je 3,61\%.

Ključne riječi: puzanje; stupanj opterećenja; klamerica; drveni spoj

\footnotetext{
${ }^{1}$ Author is associate professor at Karadeniz Technical University, Faculty of Forestry, Department of Forest Industrial Engineering, Trabzon, Turkey.

${ }^{2}$ Author is PhD student at University of Sopron, Department of Wood Sciences and Technologies, Sopron, Hungary.
} 


\section{INTRODUCTION}

\section{UVOD}

Staple connected gusset-plate joints can be defined as joints in which at least two elements in a furniture frame structure are connected by the driving of staples through the gusset-plate into the elements. The gussetplate can be metal, wood or wood-based composites such as wood or plywood. Plywood is generally used as gusset-plate because of its excellent tensile strength (APA, 1997). Since staple connected gusset-plate joints have a higher shear resistance, they connect the places such as the stump and the front rail joints, which were exposed to excessive shear loads in the upholstered furniture frame structure as shown in Figure 1.

Staples as metal fasteners resist horizontal shear forces rather than direct withdrawal forces, particularly during use in furniture frames (Zhang and Maupin, 2005). Therefore, the lateral shear resistance of the staple connected joint depends on the staple holding performance of the wood material used.

Wood material, as a popular product today; is used to achieve many purposes at functional, environmental and aesthetic levels. Wood shows a time-dependent behavior like most materials (Peng et al., 2020). With time, this time-dependent behavior leads to a deformation of the material under load (Kojima and Yamamoto, 2004). This mechanical deformation is called creep (Holzer et al., 1989; Navi and Stanzl-Tschegg, 2009; Du et al., 2013). In creep tests, the material is subjected to a constant loading and the stresses at loading point are followed for a certain period of time.

Creep deformation is quite important in the design of most products. Even though MOR is at an acceptable level, creep deformation is treated as a more disturbing perception for customers. Therefore, creep deformation is an issue to be considered. Moreover, customer satisfaction is considered as an important element in the design of furniture products.

In the modern furniture industry, a joint should meet the load over the whole lifetime of furniture. Therefore, it is not enough to evaluate only the short term behavior after assembling (Dias et al., 2018). When a joint is subjected to load, it deforms. If it is subjected to loading over a certain time, creep defor-

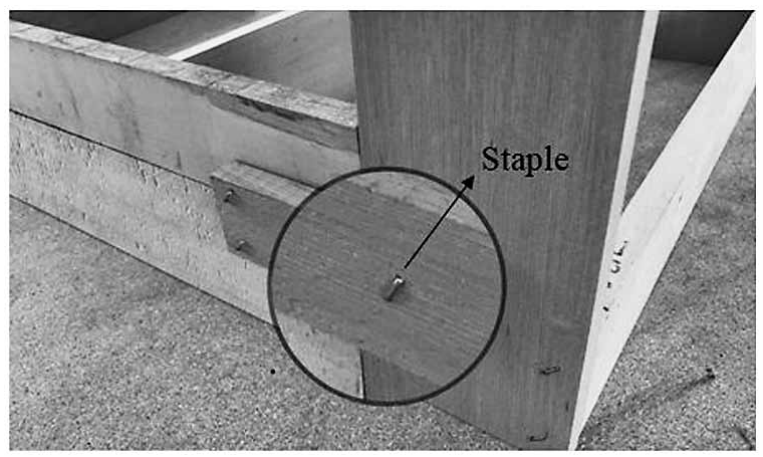

Figure 1 A sofa joint connected with staple exposed to lateral loads

Slika 1. Spoj dvosjeda povezan klamericom izložen bočnim opterećenjima mation increases with time. Therefore, creep deformation should be considered in joints.

The performance of a wooden structure is closely related to the joints in the structure or the behavior of joints between the materials (members). Most creep patterns related to the joint are based on studies on lateral shear stiffness. For example, the reduction of lateral shear stiffness of dowel-nailed and nut-screwed joints has been examined (Morlier, 1994; Polensek, 1982).

Smardzewski et al. (2013) studied the effect of creeping on changes in the rigidity of selected joints used in constructions of upholstered furniture by changing modulus of elasticity. As a result of the study, it was observed that creeping made a significant change in the mechanical quality of the tested joints by decreasing the modulus of elasticity by $11 \%-16 \%$.

$\mathrm{Xu}$ et al. (2015) investigated the effects of pressure load magnitude of the seat cushions commonly used in upholstered furniture and the force-deformation-time behavior of the material used in cushion fabrics. The results showed that the creep behavior of furniture seat cushions consisting of foam, spring and fabric materials can be defined, respectively. The statistical analysis of the experimental data in this study showed that the magnitude of the loads examining the creep behavior had significant effects on the viscoelastic constants in the mathematical expressions to define the force-deformation-time behavior of the cushions evaluated.

Li et al. (2019) investigated the creep behavior of balsa wood covered with glass fiber-reinforced polymer from both surfaces. First, static bending test was conducted and ultimate bearing capacities were determined for the specimens. Based on the bearing capacity, four load levels were determined as $20 \%, 40 \%, 60 \%$ and 80 $\%$ for creep loading. Results showed that at small load levels, such as $20 \%$ and $40 \%$, specimens showed linear viscoelastic behavior; however, they showed creep failure at higher load levels, $60 \%$ and $80 \%$.

There have been few studies so far that fully explained the creep properties of wood material, both theoretically and practically. Mostly, tests were carried out statically for a short time. However, practical applications and necessary rules for examining the effects of creep of wood material on the service life have not been developed yet. In the furniture area, there is almost no creep study on the joints used for building furniture frames such as sofas. In particular, almost no study has been conducted on creep behavior of the staple connected gusset-plate joints made of beech, alder and Scotch pine, which are mostly used in Turkey and worldwide furniture manufacturing.

The main purpose of this study was to investigate and interpret the creep properties of the joints made of different wood species under different load levels. The specific objectives of this study were to: 1) determine the load levels to be applied for creep testing by applying different percentages of the maximum static load value of the joint as creep load, 2) examine the creep behavior of furniture joints as a result of using different 
wood species, 3) quantitatively compare the creep behavior of the joints according to the static behavior of the joints.

\section{MATERIALS AND METHODS}

\section{MATERIJALI I METODE}

\subsection{Material \\ 2.1. Materijal}

In this study, creep behavior of the joints made of Beech (Fagus orientalis), Scotch pine (Pinus sylvestris) and Alder (Alnus glutinosa), which have recently gained a new place in Turkish furniture production, have been investigated. For the static shear test, 30 joint specimens for each wood species, i.e. 90 joints in total, were tested. On the other hand, a total of 27 joint specimens were loaded for creep test for three replications for each wood species. The densities of these wood species are shown in Table 1.

As shown in Table 1, beech wood had the highest density value, followed by alder and Scotch pine. The densities of the materials were determined according to TS 2472 standard (TS 2472, 1976). In this study, wood species were used as the main material and the plywood with 9 layers of Scotch pine veneers was used as side material. Each layer of the plywood was prepared perpendicular to one another, and the surface layers were parallel to each other. Senco staples, coated with a nitro-cellulosic based corrosion inhibiting layer, were

Table 1 Densities of wood species used in joint structure Tablica 1. Gustoća vrsta drva upotrijebljenih za izradu spojeva

\begin{tabular}{|l|c|c|c|c|}
\hline \multirow{2}{*}{} & \multicolumn{4}{|c|}{ Wood species / Vrsta drva } \\
\cline { 2 - 5 } & $\begin{array}{c}\text { Scotch Pine } \\
\text { Borovina }\end{array}$ & $\begin{array}{c}\text { Alder } \\
\text { Johovina }\end{array}$ & $\begin{array}{c}\text { Beech } \\
\text { Bukovina }\end{array}$ & $\begin{array}{c}\text { Plywood } \\
\text { Furnirska } \\
\text { ploča }\end{array}$ \\
\hline $\begin{array}{l}\text { Density, } \\
\mathrm{g} / \mathrm{cm}^{3} \\
\text { Gustoća } \\
\mathrm{g} / \mathrm{cm}^{3}\end{array}$ & $0.45(2)$ & $0.51(1)$ & $0.54(4)$ & $0.64(4)$ \\
\hline
\end{tabular}

The values in parenthesis indicate the coefficient of variation. / $U$ zagradama je naveden koeficijent varijacije.

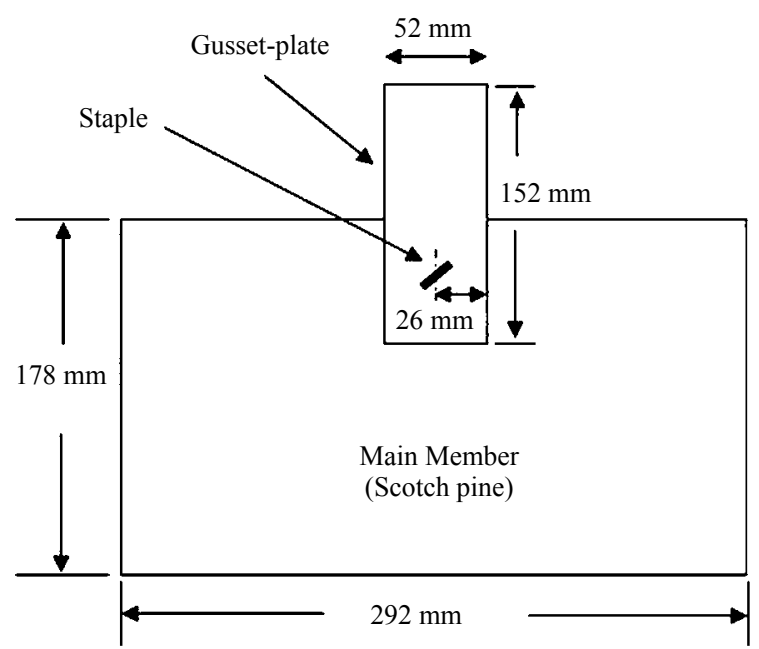

Figure 2 A joint made of Scotch pine Slika 2. Spoj izrađen od borovine

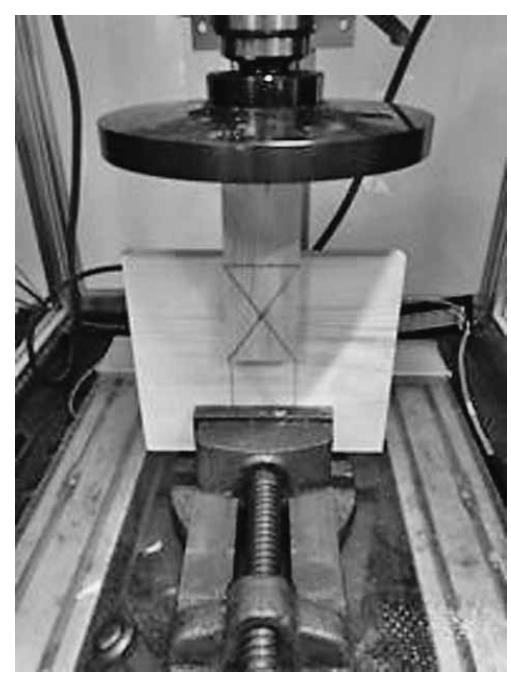

Figure 3 Static shear test for single staple Scotch pine joint Slika 3. Statički test na smicanje spoja s klamericom izrađenoga od borovine

used as metal fasteners in the attaching of the joint members. Staples have a leg length of $38 \mathrm{~mm}$ and a crown width of $11 \mathrm{~mm}$. When attaching the joint members, the staple is driven into the assembled members at an angle of $45^{\circ}$ to ensure the best connection between the members. Figure 2 shows a typical wood joint made of Scotch pine.

\subsection{Method}

\subsection{Metoda}

\subsubsection{Static shear test}

2.2.1. Statičko ispitivanje smicanja

In order to determine the load levels to be applied for creep test, 30 single-staple joint specimens were prepared from each wood species and subjected to static shear test at a loading rate of $2.5 \mathrm{~mm} / \mathrm{min}$ on MTS Criterion Model 45 Universal testing machine, and static shear loads of the joints were determined. This test was conducted based on ASTM D 1761 standard (ASTM 1761, 2010). Figure 3 shows the static shear test for single-staple wood joints.

\subsubsection{Creep test}

\subsubsection{Ispitivanje puzanja}

In order to determine the load levels required for the creep test, firstly, static shear loading was applied to the joints, and then the maximum shear load values were obtained and converted from Newton (N) to $\mathrm{kg}$. Creep test was carried out by taking certain percentage values of the maximum shear values in $\mathrm{kg}$ and hanging them to the joint specimens in weight. Figure 4 shows a representative of the five test stations prepared for this creep test.

The deflection measurement was carried out with dial gauges with $0.001 \mathrm{~mm}$ accuracy and 0-30 mm measuring rod. The measurements were continuously monitored daily and this monitoring ranged from 1 day to 103 days depending on the behavior of the joint specimens under load. Creep deformation at the joints was recorded based on each movement in the dial 


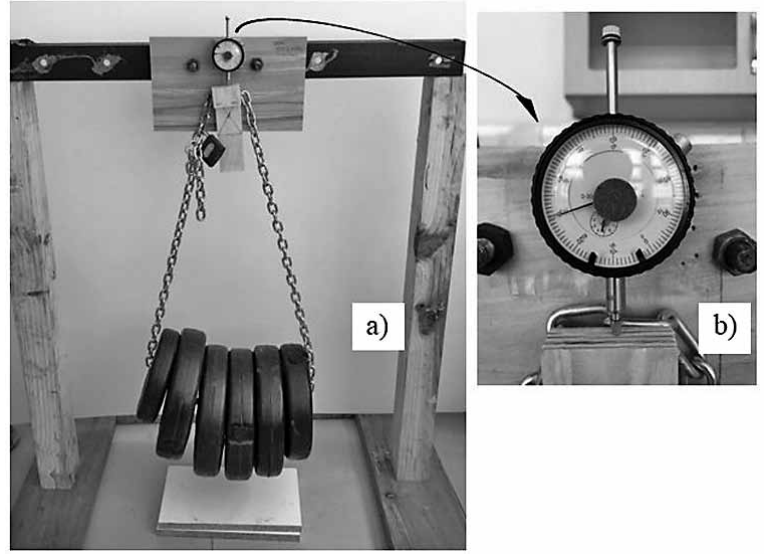

Figure 4 a) Creep test station b) Dial gauge

Slika 4. a) Oprema za ispitivanje puzanja, b) komparator

gauge. Figure $4 \mathrm{~b}$ shows the dial gauge in which creep deformation is read.

\section{RESULTS AND DISCUSSION}

\section{REZULTATI I RASPRAVA}

\subsection{Static shear test and creep test}

3.1. Statičko ispitivanje smicanja i ispitivanje puzanja

The average displacement values of each wood joint group evaluated as static shear test results given in this study are presented in Table 2. As shown in the

Table 2 Maximum static displacements Tablica 2. Najveći statički pomaci

\begin{tabular}{|l|c|c|c|}
\hline \multirow{2}{*}{} & \multicolumn{3}{|c|}{ Wood species / Vrsta drva } \\
\cline { 2 - 4 } & $\begin{array}{c}\text { Scotch Pine } \\
\text { Borovina }\end{array}$ & $\begin{array}{c}\text { Alder } \\
\text { Johovina }\end{array}$ & $\begin{array}{c}\text { Beech } \\
\text { Bukovina }\end{array}$ \\
\hline $\begin{array}{l}\text { Average displacement, } \\
\text { mm } \\
\text { Prosječni pomak, mm }\end{array}$ & $4.96(19)$ & $4.89(18)$ & $4.63(18)$ \\
\hline
\end{tabular}

The values in parenthesis indicate the coefficient of variation. / $U$ zagradama je naveden koeficijent varijacije.

Table 3 Statistical comparison of static shear resistance values (in $\mathrm{N}$ and $\mathrm{kg}$ ) obtained from each wood species

Tablica 3. Statistička usporedba vrijednosti statičkog otpora na smicanje ( $\mathrm{u} \mathrm{N} \mathrm{i} \mathrm{kg)} \mathrm{dobivenih} \mathrm{za} \mathrm{ispitivane} \mathrm{vrste} \mathrm{drva}$

\begin{tabular}{|l|c|c|c|}
\hline \multirow{2}{*}{\begin{tabular}{l}
\multirow{2}{*}{$\begin{array}{l}\text { Unit } \\
\text { Jedinica }\end{array}$} \\
\cline { 2 - 4 }
\end{tabular}} & $\begin{array}{c}\text { Scotch Pine } \\
\text { Borovina }\end{array}$ & $\begin{array}{c}\text { Alder } \\
\text { Johovina }\end{array}$ & $\begin{array}{c}\text { Beech } \\
\text { Bukovina }\end{array}$ \\
\cline { 2 - 4 } & \multicolumn{3}{|c|}{$\begin{array}{r}\text { Maximum shear values } \\
\text { Najveće smične vrijednosti, N }\end{array}$} \\
\hline $\begin{array}{l}\text { Average, N } \\
\text { prosjek, N }\end{array}$ & $809(\mathrm{C})$ & $1042(\mathrm{~B})$ & $1233(\mathrm{~A})$ \\
\hline $\begin{array}{l}\text { Average, } \mathrm{kg} \\
\text { prosjek, } \mathrm{kg}\end{array}$ & 83 & 106 & 125 \\
\hline
\end{tabular}

LSD: $53.57 \mathrm{~N}$

The same letters in parentheses indicate homogeneity groups. / Ista slova u zagradama označuju homogene grupe. table, beech joints with the highest density show the least displacement, followed by alder joint with less density and the Scotch pine joint with the least density.

The average maximum lateral shear loads of each joint specimen are shown in Table 3 . In order to see the statistical difference among the average maximum lateral shear loads, a SAS statistical analysis model based on one- factor (wood species) at $5 \%$ significance level was run and compared with least significance difference (LSD) of $53.57 \mathrm{~N}$.

As shown in Table 3, as a result of the statistical analysis, the highest shear resistance value was obtained from the single-staple joint made of beech wood. This is followed by alder joint and Scotch pine joint.

Within the scope of this study, first of all, 30 single-staple beech joints with Scotch pine gusset-plate were prepared and their maximum static resistance loads were determined in MTS Universal testing machine in $\mathrm{N}$. These values were averaged and converted to $\mathrm{kg}$ in order to obtain creep loading information, because the creep loading values were taken as a percentage of the maximum static load of the same joints. Accordingly, the average maximum static load obtained for the beech joints is $125 \mathrm{~kg}$ as shown in Table 4, which shows all percentages determined of these average maximum shear loads. The average maximum static shear resistance loads obtained in Table 3 are presented in Table 4 for beech joint. These loads were converted from $\mathrm{N}$ to $\mathrm{kg}$ and transformed into loadable values for creep test.

According to Table 4, the load of $112.5 \mathrm{~kg}$, which is $90 \%$ of the average maximum static shear loads, was applied to single-staple beech joint and an immediate separation between the members of joints appeared. Then, $80 \%, 70 \%$ and $60 \%$ of the average maximum static shear loads of the joint, $100 \mathrm{~kg}, 87.5$ $\mathrm{kg}$, and $75.5 \mathrm{~kg}$, respectively, were applied to the beech joints and again single-staple beech joints were separated between joint members in a short time. However, the joints were able to withstand a period of time under $62.5 \mathrm{~kg}$, which is $50 \%$ of the average maximum static load. Also, the joints were able to withstand $50 \mathrm{~kg}$ and $37.5 \mathrm{~kg}$, which is $40 \%$ and $30 \%$ of the average maximum static load, respectively. Therefore, in this study, creep test load levels were determined as $50 \%, 40 \%$ and $30 \%$ of the average maximum static loads of the single-staple joints for beech and other wood species. Similarly, certain percentages of the average maximum resistance values of the material were used as different load levels in previous studies for the creep test. Likewise, Hayman (1981) studied the creep properties of three connected arch structures. These joints were subjected to $85 \%, 65 \%$, and $35 \%$ of the main buckling loads. Nilsson and Johansson (2019) studied the creep

Table 4 Percentages of average maximum static load values for beech joints to be used in creep testing

Tablica 4. Postotci prosječnih maksimalnih vrijednosti statičkog opterećenja za spojeve od bukovine koji su korišteni u ispitivanju puzanja

\begin{tabular}{|c|c|c|c|c|c|c|c|}
\hline Mean static load, $\mathrm{kg}$ & \multicolumn{6}{|c|}{ Percentage values, \% / Postotne vrijednosti, \% } \\
\cline { 2 - 8 } Srednje statičko opterećenje, $\mathrm{kg}$ & 90 & 80 & 70 & 60 & 50 & 40 & 30 \\
\hline 125 & 112.5 & 100 & 87.5 & 75.5 & 62.5 & 50 & 37.5 \\
\hline
\end{tabular}


Table 5 Creep test loading values determined for each joint made of different wood species

Tablica 5. Vrijednosti opterećenja pri ispitivanju puzanja utvrđene za spojeve izrađene od različitih vrsta drva

\begin{tabular}{|l|c|c|c|}
\hline \multirow{2}{*}{$\begin{array}{l}\text { Wood species } \\
\text { Vrsta drva }\end{array}$} & \multicolumn{3}{|c|}{$\begin{array}{l}\text { Maximum static load level, \% } \\
\text { Najeći statički stupanj opterećenja, \% }\end{array}$} \\
\cline { 2 - 4 } & 30 & 40 & 50 \\
\hline $\begin{array}{l}\text { Scotch Pine } \\
\text { borovina }\end{array}$ & 25 & 33 & 41 \\
\hline Alder/ johovina & 32 & 42.5 & 53 \\
\hline Beech / bukovina & 37.5 & 50 & 62.5 \\
\hline
\end{tabular}

properties of wood-based boards and applied bending test as static test on the specimens. For creep testing, $30 \%$ of the maximum static bending resistance value was determined and applied as creep load level. The creep test loads $(\mathrm{kg})$ for the joints made of each wood species are presented in Table 5 for this study.
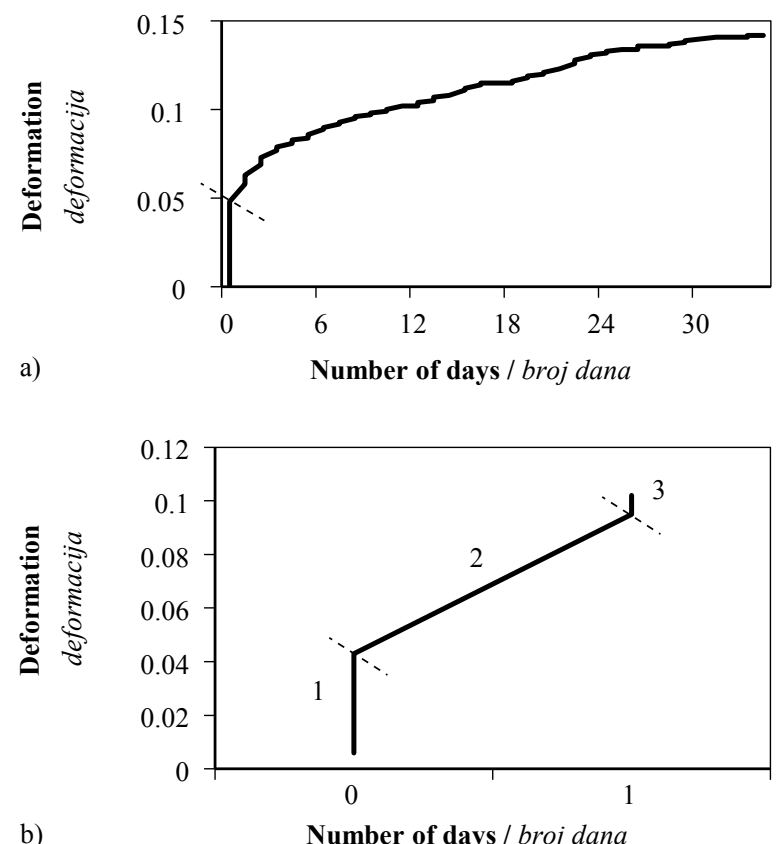

As shown in Table 6, the specimens loaded at 30 $\%$ and $40 \%$ load levels completed the creep tests in different number of days. The number of days of creep test is determined as a result of the stopping of the deformation under the creep load.

\subsection{Creep-deformation curve}

3.2. Krivulja puzanja/deformacije

The joints made of different wood species under creep load showed creep deformation-time curves at different number of stages. Creep deformation-time curves with different number of stages are as follows: (1) two stages of creep deformation, first accelerating, then decelerating; (2) three stages of creep deformation curve with accelerating, then decelerating and breaking movement; (3) also three stages of creep deformation curve with accelerating, then decelerating and stabilizing creep movement; (4) four stages creep deformation-time curve with first accelerating then
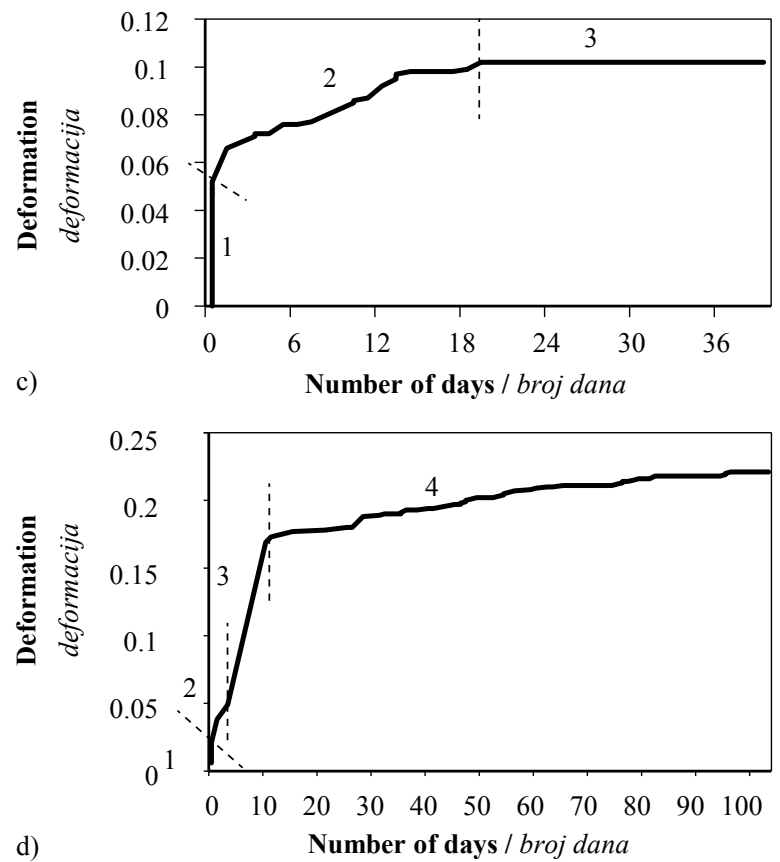

Figure 5 Creep deformation-time curves with a) two stages, mostly for alder joints, b) three stages with separation, mostly for beech joints under $50 \%$ creep load, c) three stages with stabilization, mostly for beech and Scotch pine joint under $30 \%$ and $40 \%$ creep loads d) four stages

Slika 5. Krivulje puzanja/deformacije tijekom vremena: a) dvije faze, uglavnom za spojeve od johovine, b) tri faze s odvajanjem, uglavnom za spojeve od bukovine, uz opterećenje manje od $50 \%$ pri puzanju, c) tri faze sa stabilizacijom, uglavnom za spojeve od bukovine i borovine, uz opterećenje manje od $30 \%$ pri puzanju, d) četiri faze

Table 6 Number of days of testing joints made of different wood species under creep loading

Tablica 6. Broj dana trajanja ispitivanja puzanja pri tri različita opterećenja za spojeve izrađene od različitih vrsta drva

\begin{tabular}{|c|c|c|c|c|}
\hline \multirow{2}{*}{$\begin{array}{c}\text { Load level, \% } \\
\text { Stupanj opterećenja, } \%\end{array}$} & \multirow{2}{*}{$\begin{array}{c}\text { Specimen } \\
\text { Uzorak }\end{array}$} & \multicolumn{3}{|c|}{ Wood species / Vrsta drva } \\
\cline { 2 - 5 } & & \multicolumn{3}{|c|}{ The number of days / Broj dana } \\
\cline { 2 - 5 } & I & 62 & 52 & 16 \\
\hline \multirow{3}{*}{30} & II & 66 & 34 & 80 \\
\cline { 2 - 5 } & III & 34 & 33 & 39 \\
\hline \multirow{3}{*}{40} & I & 65 & 32 & 103 \\
\cline { 2 - 5 } & II & 47 & 50 & 30 \\
\hline \multirow{3}{*}{50} & III & 56 & 75 & 2 \\
\cline { 2 - 5 } & I & 34 & 33 & 1 \\
\hline
\end{tabular}


decelerating, accelerating again and gradually stabilizing creep deformation. Figure 5 shows the curves with different stages under creep loads.

In Figure 5, each stage was separated with a dashed-line and numbered. Accordingly, a beech joint only showed a 4-stage creep deformation curve, while two beech joints showed a 2-stage curve. Most beech joints showed a three-stage creep deformation-time curve. On the other hand, at $30 \%, 40 \%, 50 \%$ loading levels, all of the alder joints showed a two-stage creep deformation-time curve. In the Scotch pine joint, 4 specimens showed two-stage and 5 specimens showed three-stage creep deformation-time curve. Results showed that the deformation-time curves obtained as a result of creep tests on wood joint had at least two stages and generally three stages. The stress-strain curve obtained by Costa and Barros (2015) had two stages as a result of creep study on epoxy adhesive protective materials. The general trend in the deformation-time curves obtained as a result of the current creep study on wood joints is similar to that established in the study by Costa and Barros (2015).

\subsection{Failure modes}

\subsection{Priroda loma}

At the end of the creep test, only two types of failure modes were observed as shown in Figure 6 . While most of the joints showed staple release mode, only 6 joints, 5 beech wood joints and 1 Scotch pine joint under $50 \%$ load level, showed complete separation of the staple from the main member.

Figure 7 shows different failure characteristics and their corresponding deformation-time curves according to each stage of a single-staple beech joint. In stage a), an increasing deformation was observed, while in stage b), decreasing creep deformation was observed. Finally in stage c), a stabilizing creep deformation was monitored. This three-stage creep deformation failure characteristic is the most observed one in this study. Figure 8 illustrates the average maximum

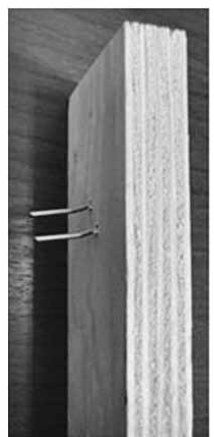

a)

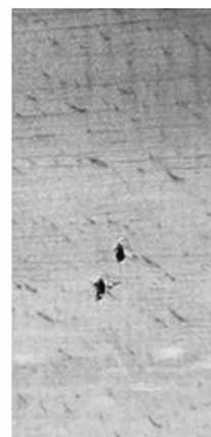

b)

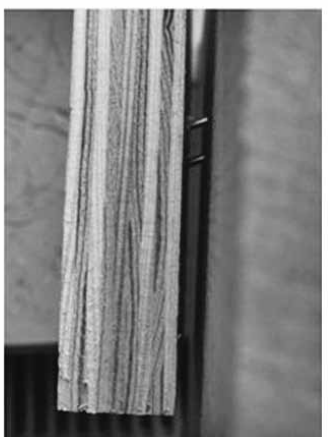

c)
Figure 6 Complete separation mode of the joint: a) staple separated from main wood member, b) damage caused by staple when withdrawing from wood material, c) other joint failure mode with staple release

Slika 6. Potpuno odvajanje spoja: a) klamerica odvojena od glavnoga drvnog dijela, b) oštećenje uzrokovano klamericom pri njezinu izvlačenju iz drvnog materijala, c) druge vrste loma s otpuštanjem klamerice
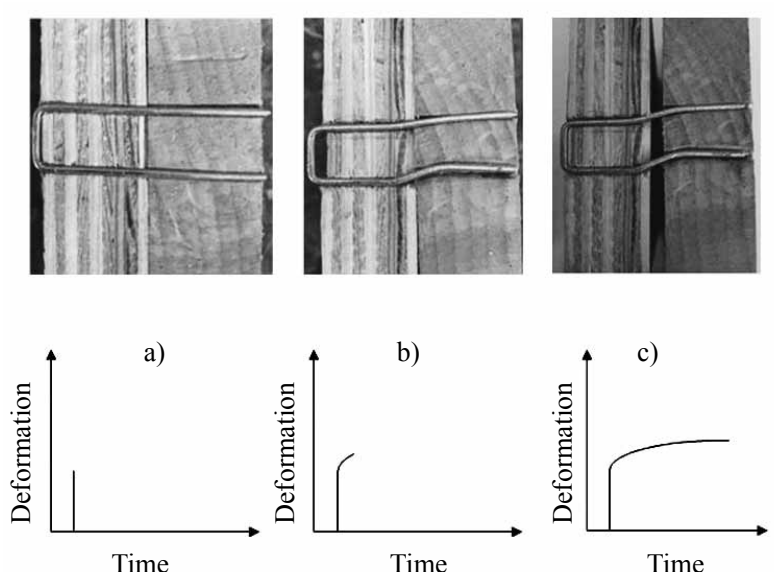

Figure 7 Cross cut view of single-stapled joints under creep load in different stages

Slika 7. Poprečni presjek spoja s klamericom pod opterećenjem pri puzanju u različitim fazama

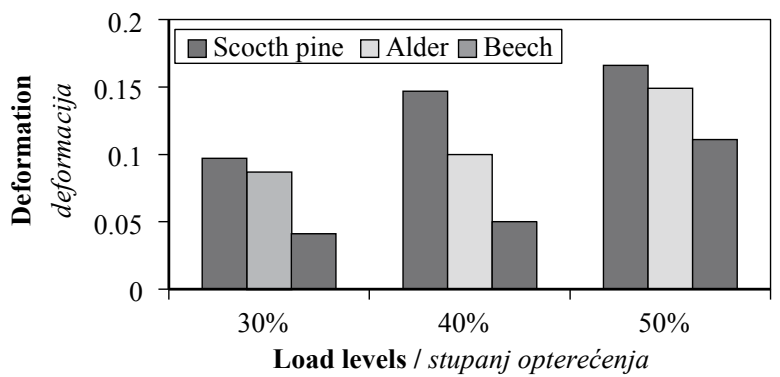

Figure 8 Creep deformation relationship between load levels and wood species as a result of one-day creep data Slika 8. Deformacija pri puzanju u ovisnosti o stupnju opterećenja i vrsti drva kao rezultat jednodnevnih podataka o puzanju

creep deformation relationship between wood species at $30 \%, 40 \%$ and $50 \%$ load levels according to first day data.

As indicated in Figure 8, the Scotch pine joints with the lowest density showed the highest amount of creep deformation under $30 \%$ load levels at the end of the first day and this was followed by the alder joints with higher density and beech joints with the highest density. The relation among different wood species on creep deformation is similar to the deformation under static lateral shear loading. Similar creep relations were observed at the load levels of $40 \%$ and $50 \%$. Accordingly, the Scotch pine joints showed the highest average creep deformation and the beech joints showed the lowest average creep deformation. It is inferred from the results that the deformation under the creep load decreases as the density of the material increases. Likewise, in his study, Niemz (1993) observed that increasing the density of the wood material decreased creep deformation values. Nilsson and Johnson (2019) examined the creep properties of wood-based panels under a long time load and stated that these panels exhibit the same creep properties as solid wood materials. These scientists stated that there is an inverse relationship between the density of wood material and creep deformation. In this respect, it is obvious that the re- 


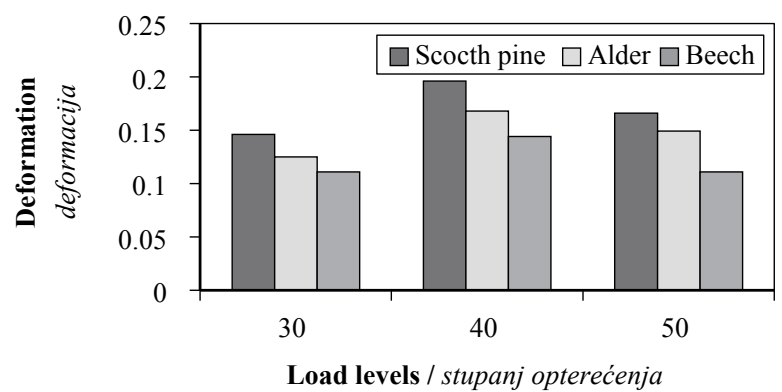

Figure 9 Creep deformation relationships between load levels and wood species as a result of common day creep data

Slika 9. Deformacije pri puzanju u ovisnosti o stupnju opterećenja i vrsti drva kao rezultat uobičajenih podataka o puzanju

sults of the current study are consistent with the previous studies. Additionally, the creep deformation on wood material joints increased as load level increased from $30 \%$ to $40 \%$ and $50 \%$. Xu et al. (2015) tested the specimens under load levels of 250, 600 and 1000 $\mathrm{N}$ and reported that creep deformation increased with increasing load levels. Figure 9 shows the average creep values obtained based on the number of common (30) days determined for each load level.

As shown in Figure 9, the lowest average maximum creep deformation at each load level (30\%, 40\%, and $50 \%$ ) was observed in the beech joints with the highest density. This was followed by the alder joints

Table 7 Comparison of joints made of different wood species according to their creep deformation

Tablica 7. Usporedba spojeva izrađenih od različitih vrsta drva prema njihovoj deformaciji puzanja

\begin{tabular}{|l|c|c|c|}
\hline \multirow{2}{*}{$\begin{array}{l}\text { Number } \\
\text { of days } \\
\text { Broj dana }\end{array}$} & \multicolumn{3}{|c|}{$\begin{array}{l}\text { Wood species / Vrsta drva } \\
\text { Creep deformation / Deformacija } \\
\text { puzanja, mm }\end{array}$} \\
\cline { 2 - 4 } & $\begin{array}{c}\text { Scotch Pine } \\
\text { Borovina }\end{array}$ & $\begin{array}{c}\text { Alder } \\
\text { Johovina }\end{array}$ & $\begin{array}{c}\text { Beech } \\
\text { Bukovina }\end{array}$ \\
\hline $1^{\text {st }}$ day & $0.136(\mathrm{~A})$ & $0.112(\mathrm{AB})$ & $0.072(\mathrm{~B})$ \\
\hline $30^{\text {th }}$ day & $0.171(\mathrm{~A})$ & $0.145(\mathrm{AB})$ & $0.123(\mathrm{~B})$ \\
\hline
\end{tabular}

The same letters in parentheses indicate homogeneity groups. / Ista slova u zagradama označuju homogene grupe. with lower density and the Scotch pine joints with the lowest density.

A statistical analysis was conducted to see the effect of wood species and load level on creep deformation of all joints by using the 1st day and 30th day creep deformation data at \% 5 significance level in SAS statistics program. As a result of the statistical analysis, the relationship between wood species and loading level was found insignificant.

Accordingly, in Table 7, the significance of creep deformation among joints was compared with LSD values of 0.040 and 0.044 , respectively, using the creep deformation data on the $1^{\text {st }}$ day and $30^{\text {th }}$ day.

As indicated in Table 7, based on creep deformation data on the first day, single-staple joints made of the lowest density Scotch pine showed significantly the greatest creep deformation. This was insignificantly but marginally followed by alder joints because the alder joint showed insignificantly less creep deformation. The beech joints, on the other hand, showed significantly lower creep deformation than the Scotch pine joints and insignificantly lower creep deformation than the alder joints. In other words, the beech joint showed the lowest creep behavior with its highest density. In general, the joints made of lower density wood were more deformed under creep load, while the lowest creep deformation was observed in joints made of wood with the highest density. An exactly similar relationship is also valid for creep deformations of the joints obtained at the end of the 30th day.

Table 8 shows the values of creep deformation of each sample in the percentage of deformation resulting from the initial static maximum load value, the average values according to the load levels and the overall average value. As shown in Table 8 , deformation increases as load level increases from $30 \%$ to $50 \%$. The overall creep deformation value of the wood joints is 3.61 $\%$ of their static deformation obtained initially. Therefore, under long time loading, a furniture joint made of these wood species is subjected to an average creep deformation of $3.61 \%$. Costa and Barros (2015) found that creep deformation observed on test specimens was $3 \%$ compared to the initial static shear test deforma-

Table 8 List of deformation values of joints made of different wood species in three different load levels under creep load, as a percentage of deformation of the same joints under static shear load

Tablica 8. Vrijednosti deformacija puzanja spojeva izrađenih od različitih vrsta drva pri tri različita stupnja opterećenja kao postotak deformacije istih spojeva pri statičkome smičnom opterećenju

\begin{tabular}{|c|c|c|c|c|c|}
\hline \multirow{2}{*}{$\begin{array}{c}\text { Load level, \% } \\
\text { Stupanj opterećenja, \% }\end{array}$} & \multicolumn{5}{|c|}{ Creep deformation amount / Iznos deformacije pri puzanju, \% } \\
\cline { 2 - 6 } & $\begin{array}{c}\text { Specimen } \\
\text { Uzorak }\end{array}$ & $\begin{array}{c}\text { Scotch Pine } \\
\text { Borovina }\end{array}$ & $\begin{array}{c}\text { Alder } \\
\text { Johovina }\end{array}$ & $\begin{array}{c}\text { Beech } \\
\text { Bukovina }\end{array}$ & $\begin{array}{c}\text { Average } \\
\text { Prosjek }\end{array}$ \\
\hline \multirow{3}{*}{30} & I. & 2.25 & 2.43 & 2.5 & \\
\cline { 2 - 6 } & II. & 5.1 & 2.82 & 2.1 & 1.81 \\
\hline \multirow{3}{*}{40} & III. & 3 & 2.68 & 2.16 & \\
\cline { 2 - 6 } & I. & 4.17 & 3.48 & 4.13 & 2.74 \\
\cline { 2 - 6 } & II. & 4.92 & 3.37 & 2.3 & 3.71 \\
\hline \multirow{3}{*}{50} & III. & 4.47 & 4.27 & 4.44 & \\
\cline { 2 - 6 } & I. & 3.13 & 4.01 & 3 & 4.37 \\
\hline
\end{tabular}


tion of the specimens. In this respect, the results of the current study are very close to the results in the study by Costa and Barros (2015).

\section{CONCLUSIONS \\ 4. ZAKLJUČAK}

Creep properties of single stapled furniture joints, made of wood species widely used in furniture industry such as Scotch pine, alder and beech, were investigated. For creep test, $30 \%, 40 \%$, and $50 \%$ were determined as load levels based on the maximum static lateral shear loads of the same joints.

Results indicated that most of the joints under creep load showed deformation curve with three stages - first accelerating then decelerating and finally stabilizing creep movement.

Based on the first day creep data, the joints made of Scotch pine with the lowest density showed significantly higher creep deformation than the joints made of beech with the highest density. This was insignificantly followed by alder joints with a medium density as compared to other wood species. This also means that the alder joints showed insignificant but mathematically observable higher creep deformation than the beech joints. As a result, increasing wood density decreased creep deformation. Additionally, results showed that increasing load levels from $30 \%$ to $50 \%$ increased the creep deformation of the wood joints.

After creep loading, the deformation of the Scotch pine, alder and beech joints was determined as $2.74 \%$, $3.71 \%$ and $4.37 \%$, respectively, of their deformation after static shear loading performed before the creep test. Ultimately, this value was obtained as $3.61 \%$ for singlestaple wood joints as the average of three wood species. In other words, the average creep deformation value of a single-staple wood joint under load levels of $30 \%, 40 \%$ and $50 \%$ was determined as $3.61 \%$.

\section{REFERENCES}

\section{LITERATURA}

1. Costa, I.; Barros, J., 2015: Tensile creep of a structural epoxy adhesive: experimental and analytical characterization. International Journal of Adhesion and Adhesives, 59: 115-124.

http://doi.org/10.1016/j.ijadhadh.2015.02.006.

2. Dias, A.; Schänzlin, J.; Dietsch, P., 2018: Design of timber-concrete composite structures: a state-of-the-art report by COST Action FP1402/WG 4, Shaker Verlag Aachen.

3. Du, Y.; Yan, N.; Kortschot, M. T., 2013: An experimental study of creep behavior of lightweight natural fiber-reinforced polymer composite/honeycomb core sandwich panels. Composite Structures, 106: 160-166. http://doi.org/10.1016/j.compstruct.2013.06.007.

4. Hayman, B., 1981: Creep buckling - A General View of the Phenomena. In: Proceedings of the Third IUTAM
Symposium on Creep in Structures, Ponter, A. R. S.; Hayhurs, D. R. (eds.). Berlin. Springer-Verlag.

5. Holzer, S. M.; Loferski, J. R.; Dillard, D. A., 1989: A review of creep in wood: concepts relevant to develop long-term behavior predictions for wood structures. Wood and Fiber Science, 21 (4): 376-392.

6. Kojima, Y.; Yamamoto, H., 2004: Efect of microfbril angle on the longitudinal tensile creep behavior of wood. Journal of Wood Science, 50: 301-306.

http://doi.org/10.1007/s10086-003-0565-3.

7. Morlier, P., 1994: Creep in timber structure. London Glasgow Weinheim New York Tokyo Melborn Madras. Taylor \& Francis.

8. Navi, P.; Stanzl-Tschegg, S., 2009: Micromechanics of creep and relaxation of wood. A review cost action E35 2004-2008 Wood machining-micromechanics and fracture. Holzforschung, 63 (2): 186-195. http://doi.org/10.1515/HF.2009.013

9. Niemz, P., 1993: Physics of Wood and Wood Composites [in German]. Echterdingen. DRW-Verlag, Leinfelden.

10. Nilsson, J.; Johansson, J., 2019: Bending and creep deformation of a wood-based lightweight panel: an experimental study. Wood and Fiber Science. 51 (1). http://doi.org/10.22382/wfs-2019-003.

11. Li, X.; Liu, W.; Fang, H.; Huo, R.; Wu, P., 2019: Flexural creep behavior and life prediction of GFRP-balsa sandwich beams. Composite Structures, 224: 1-12. http://doi.org/10.1016/j.compstruct.2019.111009.

12. Penk, H.; Salmen, L.; Jiang, J.; Lu, J., 2020: Creep properties of compression wood fibers. Wood and Fiber Science, 51 (1). https://doi.org/10.1007/s00226-020-01221-1.

13. Polensek, A., 1982: Creep prediction for nailed joints under constant and increasing loading. Wood Science and Technology, 15 (2): 183-192.

14. Smardzewski, J.; Klos, R.; Fabisiak, B., 2013: Determination of the impact of creeping of furniture joints on their rigidity. Turkish Journal of Agriculture and Forestry, 37 (6): 802-811. http://doi.org/10.3906/tar-1206-8.

15. Xu, W.; Wu, Z.; Zhang, J., 2015: Compressive creep and recovery behaviors of seat cushions in upholstered furniture. Wood and Fiber Science, 47(4): 431-444.

16. Zhang, J.; Maupin, M., 2005: Face lateral and withdrawal resistances of staple joints in furniture-grade pine-plywood. Forest Products Journal, 54 (6): 40-46.

17. ***APA, 1997: Panel handbook \& grade glossary. Tacoma, Washington.

18. ***ASTM D 1761-10, 2010: Standard test method for mechanical fasteners in wood. ASTM International. West Conshohocken, PA.

19. ***TS 2472, 1976: Unit volume weight determination for physical and mechanical experiments on wood. Ankara.

\section{Corresponding address:}

Assoc. Prof. SAMET DEMIREL

Karadeniz Technical University

Faculty of Forestry

Department of Forest Industrial Engineering

61080, Trabzon, TURKEY

e-mail: sdemirel@ktu.edu.tr 